\title{
CHARACTERISATION OF DAIRY FARMING SYSTEMS IN UPPER EGYPT
}

\section{M.A. Khalil and M. M. I. El-Ashmawy}

\author{
Animal Production Research Institute, Agricultural Research Center, Ministry of \\ Agriculture, Dokki, Giza, Egypt
}

\section{SUMMARY}

Ninety seven dairy farms under mixed farming system located in (El-Waqaff, 31 farms - Qafft, 27 farms -Qana, 39 farms) in Qana governorate in Upper Egypt were selected with the objectives to characterize the existing dairy farming systems. A questionnaire was designed and pre-tested to obtain data on average crop production, farm size, artificial insemination (AI), animal feeding, average milk production in dairy farms, milk revenue and feeding cost.

The results showed that average cultivated areas/farm was 23.02, 9.15 and 7.07 feddan $\left(1\right.$ feddan $\left.=4200 \mathrm{~m}^{2}\right)$ for the studied districts, respectively. Percentages of milk revenue minus feeding cost in the three districts were $23 \%,-0.04 \%$ and $.04 \%$ for local cows; $31 \%, 09 \%$ and $44 \%$ for buffalo and 22\%, 07\% and 12\% for crossbred cattle for the same districts, respectively. Average milk productions were 4.50, 5.00 and $6.42 \mathrm{~kg} /$ day for local cows, buffalo and crossbred cows in EL-Waqaff, respectively. While in Qafft and Qana the average milk production was 4.23, 5.05 and $6.79 \mathrm{~kg} /$ day and $4.10,6.02$ and $6.29 \mathrm{~kg} /$ day for the same genetic groups, respectively.

Main fodder crops per farm in summer were: sorghum (2.19, 1.20 and 1.50 kirat) ( 1 feddan $=24$ kirat), darawa $(1.37,1.11$ and 1.14 kirat $)$, respectively and alfalfa (2.17, 1.14 and 1.00 kirat), respectively in El-Waqaff, Qafft and Qana, respectively. While fodder crops per farm in winter were berseem (3.33, 1.35 and 1.26 kirat), respectively and alfalfa $(2.91,1.13$ and 0.67 kirat), respectively in those three respective areas. It could be concluded that most farmers need simple animal feeding technical inputs to improve animal productivity

\section{Keywords: Dairy farm characterization, mixed farming systems, Upper Egypt INTRODUCTION}

Studying farming systems in Upper Egypt is important so as to get a clear picture of the prevailing production systems and in particular the dairy systems and how far they have evolved over time. Milk marketing structure should also be appraised since it has been learnt from the previous studies that development of small-scale dairy system is a function of milk demand and the product delivery systems. Moreover, the fast changes in milk marketing as a consequence of a liberalized economy have created opportunities for growth in dairy production and milk outlets that have not been adequately studied in these parts of the country.

The main problem to improve animal production is animal feed which is not efficiently utilized in Egypt. In winter there is a surplus of green forage over the animal feed requirements while in summer there is shortage (Hathout et al., 1996). In addition, the concentrates are expensive where most farmers cannot afford it.

Issued by The Egyptian Society of Animal Production 
Moreover, there is a great competition for cultivated area between cash crops on one hand (corn, rice, bean and wheat) and green fodders on the other hand. Egypt still imports almost 55\% of wheat requirements (MALR, 2005). Smallholder dairy production can be improved in the mixed farming system as it offers the opportunity to diversify operations, spreads risk and provides regular income (Gryseels, 1988). The present study will help better understand common dairy systems and agriculture in Upper Egypt. Also it will help to identify constraints, and opportunities for, their improvement, and refining the recommendation domains for the pilot interventions to be selected with stakeholders: the producers, the market agents, the regulators and the policy makers.

The objective of this study was to describe existing dairy farming systems in Upper Egypt in mixed farming systems and formulate recommendation to set up policies and technical intervention.

\section{MATERIALS AND METHODS}

The present study was conducted based on the secondary and primary data collected through a questionnaire on farms that are practicing mixed dairy farming in Upper Egypt. The study was conducted on 97 dairy farms in three districts at Qana Governorate. A total of 97 farms, 31, 27 and 39 farms were selected from El-Waqaff, Qafft and Qana districts, respectively. The studied farms were selected as representative of the common dairy farms operated as mixed farming system, where animal raising and crop cultivation activities are practiced. The data on farms was collected during April 2007.

A questionnaire was developed and pre-tested on a limited number of farms with good experience in livestock practices. The data collected were average crop production, farm size, crop cost and revenue, average, animal feeding, family size and average milk production in dairy farms. Milk revenue minus feeding cost was calculated. The collected data on herd size were converted into Animal Unit (AU) according to (El-Sayes and El-Wardani, 2004). Data were analysed using SAS for Windows (1998). Three models were used to study different factors affecting milk production, green forage areas and number of lactating cows per farm. Average and percentage were calculated for technical and economic variables including milk production, animal stocking rate and farm size.

Model I was used to evaluate variation among districts, species, parity number and seasons in milk production. Model II was to test impact of districts, farm size, districts interacting with farm size and number of animal units on cultivated green forage areas /farm. Model III was run to test impact of districts, farm size in feddan on number of lactating cows/ herd. Details of these models are shown below.

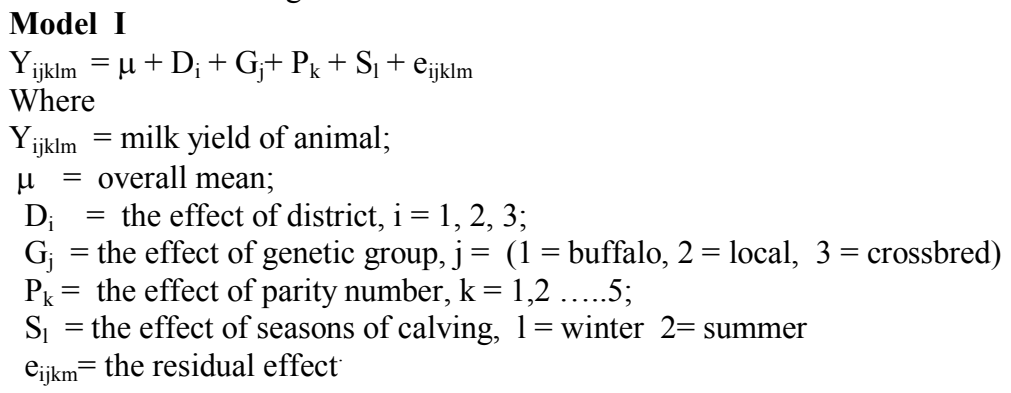




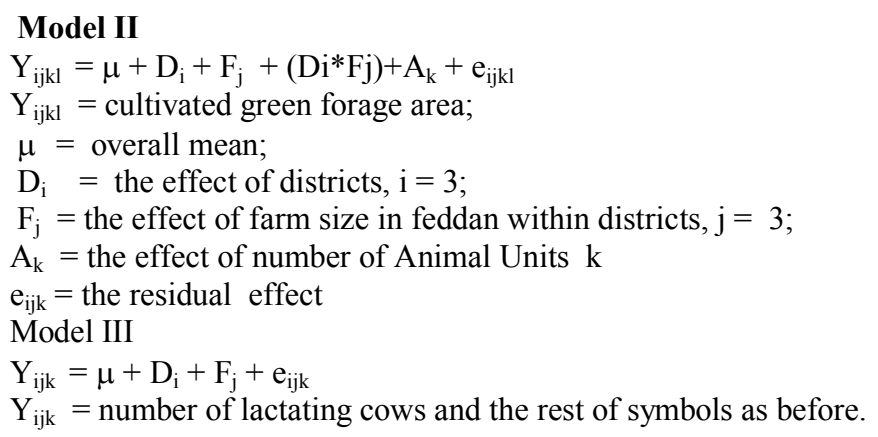

\section{RESULTS AND DISCUSSION}

Results indicated that a significant effect of districts $(\mathrm{P}<0.05)$ was shown on milk yield (Table1). According to Model I milk yield was significantly higher in Qafft than El-Weave and Qana. This result could be due to that, the dairy farms in Qafft are used to some technical packages such green forage conservation and use fenugreek and molasses as feed additives in dairy cows ration. While milk yield showed no significant difference between El-waqaff and Qana.

Table 1. Least squares means (LSM) $( \pm$ SE) for milk yield per districts, species parity number and seasons of the year

\begin{tabular}{lccc}
\hline Effects & No. of animals & \multicolumn{2}{c}{ Milk yield per lactation } \\
\cline { 3 - 4 } & & LSM & \pm SE \\
\hline Overall mean & 714 & 1242 & 7.25 \\
Districts & & & \\
$\quad$ El-waqaff & 345 & $1248^{\mathrm{b}}$ & 11.5 \\
Qafft & 117 & $1314^{\mathrm{a}}$ & 20.7 \\
Qana & 252 & $1236^{\mathrm{b}}$ & 13.1 \\
Genetic group & & & \\
Buffalo & 176 & $1256^{\mathrm{b}}$ & 15.8 \\
Local & 264 & $881^{\mathrm{c}}$ & 15.1 \\
Crossbred & 274 & $1659^{\mathrm{a}}$ & 12.1 \\
Parity No. & & & \\
1 & 133 & $1251^{\mathrm{c}}$ & 17.9 \\
2 & 135 & $1284^{\mathrm{b}}$ & 17.3 \\
3 & 153 & $1309^{\mathrm{a}}$ & 16.2 \\
4 & 141 & $1283^{\mathrm{b}}$ & 17.3 \\
5 & 152 & $1198^{\mathrm{d}}$ & 16.9 \\
Seasons of calving & & & \\
Winter & 313 & $1410^{\mathrm{a}}$ & 12.3 \\
Summer & 401 & $1120^{\mathrm{b}}$ & 10.8 \\
\hline abc & &
\end{tabular}

Parity number was significant effect $(\mathrm{P}<0.05)$ on milk yield between 3 and each of 1, 2, 4 and 5. While, between 2 and 4 were not significant. This results my be attributed to that milk yield tended to be higher in parity number 3 and 4 because the 
body has already reached the full size. The first parity cows convert part of their feed to body construction while for the fifth parity or more cows milking glands are less efficient and begin to deteriorate. The average milk yields for three species reached the peak in the 3-4 months of lactation (Hathout et al., 1996). This relative long time to reach the peak might be partly attributed to parity number and inadequate feeding regime before parturition. The reason is that, most farmers do not rely on themselves to produce their own heifers, to benefit from milk sale and avoid high mortality of young calves. Farmers prefer to purchase cows in the second, third or forth lactation. Most farmers tended to get rid of low producing cows after the fifth parity. These results agree with (Hathout et al., 1996) who found that average milk yield per lactation in the delta region ranged between 1466 and $2109 \mathrm{~kg}$ for buffalo and 1465 and $2540 \mathrm{~kg}$ for crossbred cows.

Milk yield in winter was highly significant $(\mathrm{P}<0.01)$ higher than summer season. This result might be attributed to the quality of green forage in winter than summer because, berseem with alfalfa are the main green forage farmers give a big quantity that caver animal feeding requirements. While in summer sorghum and darawa has low protein percentage they can not cover animal feeding requirement. In addition summer is too hot for animals which has negative effect on feed consumption. It was believed that many farmers arrange their breeding plan so that their cows deliver in the summer season to get more milk because average of green forage area in summer represent $52.75 \%$ of cropping pattern while, in winter was $31.81 \%$. From the results in table 1 could conclude that balanced rations, hot climate might be play a big role in milk production.

Data in table (2) shows that the effect district, farm size in feddan, interaction between (district and farm size) and Animal Unit (AU) on cultivated green forage areas. According to Model II the districts have no significantly effect on cultivated green forage area. Farm size has significant $(\mathrm{P}<0.05)$ only was between farm size $>20$ feddan and other two farm sizes this results which could be due to that, the positive relationship between dairy farms size and size of green forage areas the forage area increased as the farm size increased.

The effect of farm size interaction with districts on cultivated green forage area was not significant. Results indicated that as number of AU per farm increased effect green forage area significantly increased $(\mathrm{P}<0.05)$. Table $(3)$ shows the effect of districts and farm size on number of lactating cows per farm. Results indicated that a significant effect of districts $(\mathrm{P}<0.05)$ on number of lactating cows per farm. According to Model III number of lactating cows were significantly higher $(\mathrm{P}<0.05)$ in El-Waqaff than either Qafft or Qana and Qana was significantly higher than Qafft. This result could be due to that, the dairy farms in El-Waqaff owned larger herds than Qafft and Qana that might be due to organic fertilizer requirement to reclaim land and it consider as a part of social customs.

From the present results observed that farmers in El-Waqaff hold large number of local cows it is easy to manage the herd with a big amount of crops by- products available as a feed resources. In addition local animal more tolerant with desert conditions plus is has annul regular calving. Also the difference between Qana and Qafft was significant that might be attributed to availability of milk markets in Qana. Farmers in Qana holding buffalo cows because buffalo milk preferable for drinking and home consumption. 
Table 2. Least squares means of green forage areas (GFA), districts (D), farm size (S) and (AU) in El-Waqaff, Qafft and Qana

\begin{tabular}{|c|c|c|c|}
\hline \multirow[t]{2}{*}{ Effects } & \multirow{2}{*}{$\begin{array}{l}\text { No. of } \\
\text { farms }\end{array}$} & \multicolumn{2}{|c|}{ Green forage areas in feddan } \\
\hline & & LSM & $\pm \mathbf{S E}$ \\
\hline Overall mean & 97 & 3.66 & 0.29 \\
\hline \multicolumn{4}{|l|}{ Districts (D) } \\
\hline El-waqaff & 31 & 5.08 & 0.72 \\
\hline Qafft & 39 & 3.85 & 0.88 \\
\hline Qana & 27 & 4.47 & 0.79 \\
\hline \multicolumn{4}{|l|}{ Farm size (S) } \\
\hline$\leq 10$ feddan & 51 & $2.89^{\mathrm{b}}$ & 0.66 \\
\hline$>10-\leq 20$ feddan & 29 & $4.15^{\mathrm{b}}$ & 0.61 \\
\hline$>20$ Feddan & 17 & $6.36^{\mathrm{a}}$ & 1.01 \\
\hline \multicolumn{4}{|l|}{ Farm size $*$ districts $(D * S)$} \\
\hline$\leq 10$ feddan - El-waqaff & 3 & 3.02 & 1.67 \\
\hline$\leq 10$ feddan - Qafft & 19 & 2.62 & 0.76 \\
\hline$\leq 10$ feddan - Qana & 29 & 3.04 & 0.67 \\
\hline$>10-\leq 20$ feddan - El-waqaff & 15 & 4.54 & 0.80 \\
\hline$>10-\leq 20$ feddan - Qafft & 6 & 3.96 & 1.23 \\
\hline$>10-\leq 20$ feddan - Qana & 8 & 3.96 & 1.07 \\
\hline$>20$ feddan - El-waqaff & 13 & 7.71 & 0.89 \\
\hline$>20$ feddan - Qafft & 2 & 4.96 & 2.06 \\
\hline > 20 feddan - Qana & 2 & 6.41 & 2.04 \\
\hline \multicolumn{4}{|l|}{ Animal Unit (AU) } \\
\hline$>0-\leq 7$ & 34 & $2.51^{\mathrm{c}}$ & 0.77 \\
\hline$>7-\leq 20$ & 44 & $4.10^{\mathrm{b}}$ & 0.52 \\
\hline$>20$ & 19 & $6.80^{\mathrm{a}}$ & 0.91 \\
\hline
\end{tabular}

Table 3. Least squares means of lactating animals and farm size in El-Waqaff, Qafft and Qana

\begin{tabular}{lccc}
\hline Effects & $\begin{array}{c}\text { No. of } \\
\text { farms }\end{array}$ & \multicolumn{2}{c}{ Lactated cows in three districts } \\
\cline { 3 - 4 } & 97 & LSM & \pm SE \\
\hline Overall mean & & 7.42 & 0.40 \\
Districts & 31 & $10.41^{\mathrm{a}}$ & 0.75 \\
El-waqaff & 27 & $5.83^{\mathrm{c}}$ & 0.87 \\
Qafft & 39 & $8.09^{\mathrm{b}}$ & 0.79 \\
Qana & & & \\
Farm size in feddan & 51 & $6.13^{\mathrm{c}}$ & 0.64 \\
$\leq 10$ & 29 & $7.39^{\mathrm{b}}$ & 0.77 \\
$>10-\leq 20$ & 17 & $10.81^{\mathrm{a}}$ & 1.08 \\
$>20$ & \multicolumn{3}{c}{}
\end{tabular}


Number of lactating cows were highly significant by $(\mathrm{P}<0.01)$ the highest for $(>20$ feddan $)$ and the lowest for $(<10$ feddan $)$ and it was significant between farm size ( $>10-\leq 20$ feddan) and ( $<10$ feddan). Data in table 3 shows positive relationship between cultivated area and number of AU with green forage area this result might be attributed to high proportion of dairy cows in a large herd size and cultivated areas than small herd size.

The results in Table (4) indicated that almost two third farmers in El-Waqaff and Qafft heard about AI, but they reported that it was not available, while almost $10 \%$ of the farmers in the same areas mentioned that AI was unknown. There were $25.8 \%$ and 19.1 of farmers in El-Waqaff and Qana said that they did not trust of AI technique. AI applied in Qafft for about one quarter of studied farm and $21.4 \%$ in Qana. Farmers in El-Waqaff district refused to apply AI techniques probably related to the herd structure where local breed is dominant and calves stayed with their mothers for suckling until dry-off it might also attribute to the distance between farms location and the veterinary administration.

Table 4. Artificial Insemination (AI) practices in El-Waqaff, Qafft and Qana

\begin{tabular}{lcccc}
\hline & \multicolumn{4}{c}{ Artificial Insemination (AI) } \\
\cline { 2 - 5 } & $\begin{array}{c}\text { Not available } \\
\text { \% }\end{array}$ & $\begin{array}{c}\text { Unknown } \\
\text { \% }\end{array}$ & $\begin{array}{c}\text { No trusting } \\
\%\end{array}$ & $\begin{array}{c}\text { Applied } \\
\%\end{array}$ \\
\hline El-Waqaff & 64.5 & 9.7 & 25.8 & 0.0 \\
Qafft & 63.0 & 11.1 & 0.0 & 25.9 \\
Qana & 26.2 & 33.3 & 19.1 & 21.4 \\
\hline
\end{tabular}

The average adoption rate for $\mathrm{AI}$ in the three districts was 0.0, 4.3 and 4.9 times per farm in Qafft and Qana districts.

\section{Animal feeding systems of three distracts:}

Daily feeding systems in summer per farm are presented in Table 5. Sorghum, darawa and alfalfa were the main fodder crops. The amount of concentrate given to buffalo showed little differences to cow i.e. 2.93, 5.17 and $4.00 \mathrm{~kg} /$ day for adult's animals and $1.33,1.79$ and $0.99 \mathrm{~kg}$ /day for follower in the three areas, respectively. The stocking rate, counted as the result of the average green forage consumption in cultivated areas per farm divided over the average AU of the same farm However, it was a little bit lower in summer i.e. 3.61, 4.20 and 4.74 AU/feddan for the same studied areas, respectively. In other words, each Animal Unit were given green forage for 6.79, 7.75 and 8.45 kirat in summer for El-Waqaff, Qafft and Qana, respectively.

On the other hand, in winter season feeding system is presented in Table 6. Alfalfa and berseem became the main fodder crops. Green forages are fed to all animals as a group feeding so it is so difficult to calculate the quantity per dairy cow or young stock or sheep and goats.

The stocking rate were 4.66, 6.15 and $8.72 \mathrm{AU} /$ feddan in winter for El-Waqaff, Qafft and Qana, respectively. In other words, each Animal Unit were given green forage for 8.45, 7.23 and 5.39 kirat in winter for El-Waqaff, Qafft and Qana, respectively. 
Table 5. Average daily consumption of summer green forage from sorghum, alfalfa, darawa, straw and concentrate for dairy animal in El-Waqaff, Qafft and Qana districts

\begin{tabular}{|c|c|c|c|c|c|c|c|c|c|c|c|}
\hline & \multicolumn{2}{|c|}{$\begin{array}{l}\text { Sorghum/far } \\
\text { m/day }\end{array}$} & \multicolumn{2}{|c|}{$\begin{array}{l}\text { Alfalfa/farm/ } \\
\text { day }\end{array}$} & \multicolumn{2}{|c|}{$\begin{array}{l}\text { Darawa/farm } \\
\text { /day }\end{array}$} & \multirow{2}{*}{$\begin{array}{l}\text { Straw } \\
\mathrm{Kg} / \\
\text { head } \\
\end{array}$} & \multicolumn{4}{|c|}{ Concentrate feed (kg/head) } \\
\hline & Kirat & $\mathrm{Kg}$ & Kirat & $\mathrm{Kg}$ & Kirat & $\mathrm{Kg}$ & & Cows & $\begin{array}{l}\text { Foll. } \\
\text { Cows }\end{array}$ & Buff & $\begin{array}{l}\text { Foll. } \\
\text { Buff }\end{array}$ \\
\hline $\begin{array}{l}\text { El- } \\
\text { Waqaff }\end{array}$ & 2.19 & 800 & 2.17 & 543 & 1.37 & 685 & N.A. & 2.69 & 1.29 & 2.93 & 1.33 \\
\hline Qafft & 1.20 & 655 & 1.14 & 285 & 1.11 & 553 & 3.48 & 5.17 & 1.71 & 5.17 & 1.79 \\
\hline Qana & 1.50 & 720 & 1.00 & 250 & 1.14 & 568 & 4.68 & 3.99 & 0.97 & 4.00 & 0.99 \\
\hline
\end{tabular}

Table 6. Average daily consumption of winter green forage and dairy animals and concentrate for fattening animal/day in El-Waqaff, Qafft and Qana districts

\begin{tabular}{|c|c|c|c|c|c|c|c|}
\hline & \multicolumn{2}{|c|}{ Alfalfa/farm/day } & \multicolumn{2}{|c|}{$\begin{array}{l}\text { Berseem/farm/ } \\
\text { day }\end{array}$} & \multicolumn{2}{|c|}{ Fattening } & \multirow{2}{*}{$\begin{array}{l}\text { Av. Conc. } \\
\text { annual } \\
\text { Price } \\
\text { (L.E./ton) }\end{array}$} \\
\hline & Kirat & $\mathrm{Kg}$ & Kirat & $\mathrm{Kg}$ & $\begin{array}{l}\text { Kg conc. } /<300 \\
\mathrm{~kg} \mathrm{BW}\end{array}$ & $\begin{array}{l}\mathrm{Kg} \text { conc. } />300 \\
\mathrm{~kg} \mathrm{BW}\end{array}$ & \\
\hline $\begin{array}{l}\text { El- } \\
\text { Waqaff }\end{array}$ & 2.91 & 727 & 3.33 & 1333 & 4.59 & 5.68 & 1077 \\
\hline Qafft & 1.13 & 281 & 1.35 & 538 & 5.43 & 6.57 & 1156 \\
\hline Qana & 0.67 & 167 & 1.26 & 505 & 4.50 & 5.67 & 1067 \\
\hline
\end{tabular}

Results in table 5 and 6 showed that stocking rate in summer little bit lower than winter season in the three studied areas this might be attributed to that some farmers get red of some animals in summer because lack of cultivated green forage areas. By other meaning the green forage areas were given for AU in summer were higher than in winter for Qafft and Qana. While, El-Waqaff was lower this because the cultivated areas are bigger and the positive relationship between cultivates area and green forage area.

Ration given to fattening calves was based on their bodyweight, calves less than $300 \mathrm{~kg}$ got an average of $4.59,5.43$ and $4.50 \mathrm{~kg}$ concentrate/day in those three studied areas, while those above $300 \mathrm{~kg}$ got as an average of 5.68, 6.57 and $5.67 \mathrm{~kg}$ concentrate /day in the three areas, respectively. El-Sayes and El-Wardani (2004) found that in Ismalia, daily concentrate feeding ranged between $1.20 \mathrm{~kg}$ per animal in winter and $4.00 \mathrm{~kg}$ per animal in summer.

\section{Milk production costs and revenue}

Table (7) shows data of milk production cost and revenue in El-Waqaff, Qafft and Qana. El-Waqaff has the highest total milk production and daily milk yield for local cow compared to Qafft and Qana. The lactation length was the lowest in El-Waqaff while it was higher in Qafft and Qana, which had similar values. The variation among districts could be attributed to better farm management and efficient utilization of farm feeding resources. Farmers in El-Waqaff prefer raising local cows because of less daily feed cost since it was L.E. 6.97/day, compared with Qafft and Qana of L.E. 8.76/day and L.E.8.06/day, respectively. El-Sayes and El-Wardani (2004) reported that the average of daily milk yield for local cow in Ismalia was 4.10 $\mathrm{kg}$ /day and average of milk production was $858 \mathrm{~kg}$ per lactation. Daily milk revenue 
minus feed cost was $23 \%,-0.04 \%$ and $04 \%$ for the three studied areas, respectively. Similar result was found by Khalil et al. (2005) Who reported that daily milk yield over feed cost in Ismalia was $24 \%$. El-Waqaff has the best daily revenue from local cow while Qafft had losses from rearing local cows while Qana has the lowest profit from local cows.

Table 7. Average of lactation length, milk production cost and revenue per farm at El-Waqaff, Qafft and Qana districts

\begin{tabular}{|c|c|c|c|c|c|c|c|c|c|}
\hline \multirow[b]{2}{*}{ Trait } & \multicolumn{3}{|c|}{ Local cow } & \multicolumn{3}{|c|}{ Buffalo cow } & \multicolumn{3}{|c|}{ Crossbred cow } \\
\hline & $\begin{array}{c}\text { El- } \\
\text { Waqaff }\end{array}$ & Qafft & Qana & $\begin{array}{c}\text { El- } \\
\text { Waqaff }\end{array}$ & Qafft & Qana & $\begin{array}{c}\text { El- } \\
\text { Waqaff }\end{array}$ & Qafft & Qana \\
\hline Av. (LL) (d) & 186 & 197 & 197 & 240 & 232 & 208 & 256 & 248 & 256 \\
\hline (TMP) $(\mathrm{kg})$ & 837 & 835 & 809 & 1200 & 1172 & 1253 & 1645 & 1687 & 1612 \\
\hline $\begin{array}{l}\text { Av. (TMR) } \\
\text { (L.E.) }\end{array}$ & 1591 & 1653 & 1660 & 3121 & 3165 & 3446 & 3127 & 3340 & 3305 \\
\hline (DMP) (kg) & 4.50 & 4.23 & 4.10 & 5.00 & 5.05 & 6.02 & 6.42 & 6.79 & 6.29 \\
\hline $\begin{array}{l}\text { Av. Price/kg } \\
\text { milk (L.E) }\end{array}$ & 1.90 & 1.98 & 2.05 & 2.60 & 2.70 & 2.75 & 1.90 & 1.98 & 2.05 \\
\hline (DMR) (L.E.) & 8.55 & 8.37 & 8.41 & 13.00 & 13.64 & 16.56 & 12.20 & 13.44 & 12.89 \\
\hline (DFC) (L.E) & 6.97 & 8.76 & 8.06 & 9.96 & 12.51 & 11.51 & 9.96 & 12.51 & 11.51 \\
\hline$(\mathrm{MR} \%)-(\mathrm{FC})$ & 23 & -4 & 4 & 31 & 9 & 44 & 22 & 7 & 12 \\
\hline
\end{tabular}

Buffalo milk production in the studied areas showed different results. Qana had the lowest lactation length while; it had the bigger quantity of daily milk production from buffaloes. The lactation length in El-Waqaff and Qafft was 240 and 232 days, respectively, while in Qana was 208 days. Average daily milk production was 5.00, 5.05 and $6.02 \mathrm{~kg} /$ day for the same studied areas, respectively. Total milk production was 1200,1172 and $1253 \mathrm{~kg} /$ lactation. El-Ashmawy et al. (2006) who found that the average buffalo milk production and total milk production in small farms in west delta region was $6.20 \mathrm{~kg}$ /day and $1546 \mathrm{~kg}$ per lactation. Farmers in Qana are raising buffalo for milk production due to the high consumer desire and buffalo milk profitability compared with cows milk.

Average profit from buffalo milk Qana was the highest (44\%) compared with ELWaqaff and Qafft 31\% and 9\% respectively. Almost the similar results were found by Shelby et al. (2005) who found that buffalo milk revenue was $40 \%$ in Ismalia. In addition, Qana has some collection centres close to milk producers and this is the reason to explain that milk is easy to be market.

Qafft had the highest total milk production per lactation and daily milk yield for crossbred cows compared to El-Waqaff and Qana. The variation among the three districts could be attributed to that farmers applied some feeding technical packages (molasses, fenugreek as additives and green forage conservation), Besides, farmers at Qafft prefer the crossbred cows as they delivered healthy calves for fattening due to the availability of green forage and concentrate over the year. The highest daily feed cost was in Qafft. Although crossbred milk production at Qafft was the highest, milk revenue over feed cost was the lowest, this might be attributed to the higher availability of feed. 
El-Sayes and El-Wardani (2004) reported that the average daily milk yield for crossbred cow in Ismalia was $6.50 \mathrm{~kg}$ /day it is close to three studied areas. But total milk production in Ismalia was $1911 \mathrm{~kg}$ /lactation much higher than the studied areas. The big difference attributed to lactation length in Ismalia was 294 days while in studied areas were 256, 248 and 256 days, respectively.

\section{Landholding and use pattern:}

Percentage and cultivated area allocated for different crops during winter in the three studied areas are presented in Table (8). Farmers at El-Waqaff had larger farm size average (23.02 feddan.) than those at Qafft average (9.15 feddan) and Qana average (7.07 feddan). Farmers may attribute it to settlement ownership of the land after reclamation. Percentages of cultivated areas for green forage (berseem and alfalfa) were $33.66 \%, 31.80 \%$ and $25.46 \%$ of the farm size in El-Waqaff, Qafft and Qana, respectively.

Percentages of wheat cultivated areas were $17.42 \%, 21.09 \%$ and $27.58 \%$ of total winter areas in El-Waqaff, Qafft and Qana, respectively. The overall percentage of green forage area was $31.81 \%$ of the farm size in winter season. Farms in El-Waqaff, Qafft and Qana had allocated $35.10 \%, 25.36 \%$ and $14.43 \%$ for herbs cultivation in winter, respectively. The remaining land areas of $13.81 \%, 21.75 \%$ and $32.53 \%$ in the same three districts were used for vegetables.

The most important summer crop was green forage since farmers allocated ranged between $(49.36 \%$ and $58.27 \%)$ of total cultivated area. The second important crop was maize the percentage of cultivated areas allocated for summer maize was $15.63 \%$ and $21.48 \%$. The third important crop was tomato and farmers cultivated from 13.95 $\%$ to $20.52 \%$ of total areas in the corresponding districts.

Other crops included sugar cane which was only cultivated in El-Waqaff district with average proportion of $11.28 \%$. Sesame was cultivated in El-Waqaff and Qana where the average proportions of cultivated area was $9.79 \%$ and $8.93 \%$ in El-Waqaff and Qana, respectively. The present study was focused on common dairy farms. The sugarcane was considered as one of the most important crop in Upper Egypt but it was not found in the most studied farms.

The average winter farm size was 23.02, 9.15 and 7.07 feddan per farm in ElWaqaff, Qafft and Qana, respectively. Average farm size was less in summer due to limited availability of water for irrigation adding that hot weather increases water evaporation. The results were in agreement with El-Sayes and El-Wardani (2004) who found that the average cultivated area in Ismailia and East Qantara districts, which have almost the same circumstance, were 9.07 and 7.56 feddan/farm.

The present study showed some differences between dairy farms in the same governorate. Some farmers had local cattle while others had crossbred animals or buffalo. Also the differences were found in crop rotation in type of crops between districts in the same governorate. 
Table 8. Cultivated area under different crops per farm at El-Waqaff, Qafft and Qana

\begin{tabular}{|c|c|c|c|c|c|c|c|c|}
\hline \multirow[b]{3}{*}{$\begin{array}{l}\text { Types of } \\
\text { crop in } \\
\text { feddan }\end{array}$} & \multicolumn{6}{|c|}{ Average farm size } & \multicolumn{2}{|c|}{ Overall Mean } \\
\hline & \multicolumn{2}{|c|}{ El-Waqaff } & \multicolumn{2}{|c|}{ Qafft } & \multicolumn{2}{|c|}{ Qana } & & \\
\hline & Feddan & $\%$ & Feddan & $\%$ & Feddan & $\%$ & Feddan & $\%$ \\
\hline Wheat & 4.01 & 17.42 & 1.93 & 21.09 & 1.95 & 27.58 & 2.63 & 20.11 \\
\hline Berseem & 3.76 & 16.33 & 0.98 & 10.71 & 1.03 & 14.57 & 1.93 & 14.76 \\
\hline Alfalfa & 3.99 & 17.33 & 1.93 & 21.09 & 0.77 & 10.89 & 2.23 & 17.05 \\
\hline $\begin{array}{l}\text { Av. } \\
\text { Winter } \\
\text { Green } \\
\text { forage }\end{array}$ & 7.75 & 33.66 & 2.91 & 31.8 & 1.80 & 25.46 & 4.16 & 31.81 \\
\hline Fennel & 4.58 & 19.90 & 0.34 & 3.72 & 0.00 & 0.00 & 1.64 & 12.54 \\
\hline Fenugreek & 2.28 & 9.90 & 1.71 & 18.69 & 0.00 & 0.00 & 1.33 & 10.17 \\
\hline Aniseed & 1.22 & 5.30 & 0.27 & 2.95 & 1.02 & 14.43 & 0.84 & 6.42 \\
\hline Herbs & 8.08 & 35.1 & 2.32 & 25.36 & 1.02 & 14.43 & 3.81 & 29.13 \\
\hline Vegetable & 3.18 & 13.81 & 1.99 & 21.75 & 2.3 & 32.53 & 2.49 & 19.03 \\
\hline $\begin{array}{l}\text { Av. } \\
\text { Winter } \\
\text { Farm size }\end{array}$ & 23.02 & 100 & 9.15 & 100 & 7.07 & 100 & 13.08 & 100 \\
\hline $\begin{array}{l}\text { Summer } \\
\text { Maize }\end{array}$ & 3.16 & 15.63 & 1.57 & 21.48 & 0.97 & 16.99 & 1.90 & 17.31 \\
\hline Sorghum & 3.74 & 18.50 & 1.56 & 21.34 & 1.51 & 26.49 & 2.27 & 20.47 \\
\hline Darawa & 2.25 & 11.13 & 0.77 & 10.53 & 1.03 & 18.04 & 1.35 & 12.17 \\
\hline Alfalfa & 3.99 & 19.73 & 1.93 & 26.4 & 0.77 & 13.49 & 2.23 & 20.11 \\
\hline $\begin{array}{l}\text { Av. } \\
\text { Summer } \\
\text { Green } \\
\text { forage }\end{array}$ & 9.98 & 49.36 & 4.26 & 58.27 & 3.31 & 58.02 & 5.85 & 52.75 \\
\hline Tomato & 2.82 & 13.95 & 1.5 & 20.52 & 0.92 & 16.11 & 1.75 & 15.78 \\
\hline $\begin{array}{l}\text { Sugar } \\
\text { cane }\end{array}$ & 2.28 & 11.28 & 0.00 & 0.00 & 0.00 & 0.00 & 0.76 & 6.85 \\
\hline Sesame & 1.98 & 9.79 & 0.00 & 0.00 & 0.51 & 8.93 & 0.83 & 7.48 \\
\hline $\begin{array}{l}\text { Av. } \\
\text { Summer } \\
\text { farm size }\end{array}$ & 20.22 & 100 & 7.31 & 100 & 5.71 & 100 & 11.09 & 100 \\
\hline
\end{tabular}

\section{CONCLUSION}

The present study indicated that dairy farming systems in Upper Egypt had particular characteristics under mixed farming condition. For instance, farmers located in the adjacent back desert were characterized by large cultivated area mainly occupied by green forages and herbs. In addition, greater holding capacity of animals with tendency to breed local cows as well as smaller family size in comparison with farms located in the village. Application of AI in the valley districts enabled farmer 
to raise more crossbred cattle and to produce milk for marketing in urban areas. Raising small ruminant was pronounced in the desert farms in valley areas.

Furthermore, crops and fodder crops production as well as animal productivity were greatly by several climatic conditions and availability of water. Therefore, it can be noticed the complementary and interdependency nature of the mixed farming system in these areas. Animal extension services, increased application of AI programme and conservation of green forges are important tools to upgrade animal productivity in the studied areas.

\section{ACKNOWLEDGMENT}

We would like to express our deepest heartfelt thanks to Prof. Salah Galal, Professor of animal breeding, Faculty of agricultural, Ain Shams university for his invaluable guidance, comments and suggestions.

Our deepest recognition and thanks are due to Dr. Usama El-Saied, senior researcher of animal breeding, animal production research institute for his help, motivations and continuous encouragement.

Sincerest thanks to Dr. Mohamed Youssaf, Senior Researcher of animal husbandry, animal production research institute, Buffalo research department for reading the manuscript and making very important comments.

Many thanks to extension staff in Qana governorate specially Mr. Abu Al-Hajaj and Mr. Mohamed El-Said El-Mraghen.

\section{REFERENCE}

Duncan, D. B., 1955. Multiple ranges and multiple F test. Biometrics 11:1.

El-Ashmawy M. M. I, H. B. Sammour, M. A. Khalil, M. A. El-Wardani and Y. A. Abdel-Aziz, 2006. Comparative Technical and Economic Study of Dairy Farming Systems in West Delta Region. Proceedings of The $13^{\text {th }}$ Conference of the Egyptian Society of Animal Production. Cairo Univ., Egypt 10-11Dec. pp.303:323.

El-Sayes M.F., M.A.A. El-Wardani, 2004. Dairy farm characteristics under mixed farming system in Ismailia Governorate in Egypt. Proceedings of The $12^{\text {th }}$ Conference of the Egyptian Society of Animal Production. Mansoura, Egypt 30/11 - 2/12. pp.93:102.

General Statistics Year Book, 2005. Ministry of Agriculture and Land Reclamation, Economic Affairs Sector, Central Administration for Economic.

Gryseels, G., 1988. Role of livestock on mixed smallholder farms in the Ethiopian Highlands. A case study from the Baso and Worena Wereda near Debre Berhan. Dissertation. Agricultural University, Wageningen. The Netherlands.

Hathout M.K., S.A. El-Saadany, A.S. Tabana, M.M. Ismail and I.M Gomaa, 1996. Features of dairy farming under crop-livestock mixed system in the delta region, Egypt. International symposium on buffalo resources and production systems. Inter- regional cooperative research network on buffalo - FAO 30-40.

Khalil M.A., M. M. I. El-Ashmawy, U. M. EL-Saied and M. A. El-Wardani, 2007. Dissemination constrains of technical packages in dairy farms in Upper Egypt Mansoura Uni. Journal of Agricultural Sciences, 32 (10) Oct 8113:8124. 
Khalil, M.A. T.H. Shalaby, M.A El-Wardani and M.M.I. El-Ashmawy, 2005. The use of simulation models to increase farm income under mixed farming system Proceedings of the second conference of the animal production research institute \& regional symposium of Buffalo production, Sakha, kafr El-shekh Egypt 27-29 September. 439-446

Ministry of Agricultural and Land Reclamation (MALR), 2005. General Statistics Year Book.

SAS, 1998. SAS/STAT User's Guide, release 6.03 Edition. SAS institute Inc. Cary, North Carolina USA.

Shalaby, T. H., M. A. El-Wardani, H.B.Sammour, M.A.Khalil, A.M.Ahmed and M.F. El-Sayes, 2005. Economic study of different types of dairy cattle under mixed farming system in Egypt. Proceeding of Second Conference of Animal Production Research Institute and Regional Symposium on Buffalo Production. Sakha, Kafr El-Sheikh, Egypt, Sept. 27-29. 447 - 454 
خصائص نُظم مزارع إنتاج الألبان فى صعيد مصر

مصطفى عبد الرازق خليل، محمد محمد إسماعيل العشماوى

\section{معطة بحوث الإتتاج الحيوانس، مركز البحوث الزراعية، وزارة النراعة، دقي، جيزة، مصر}

أجريت الدراسة على Y وزرعة من مربى إنتاج الألبان تحت النظم المز رعية الدختطة (إنتاج

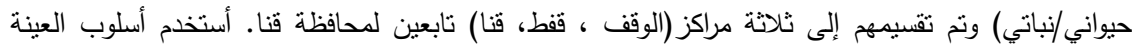

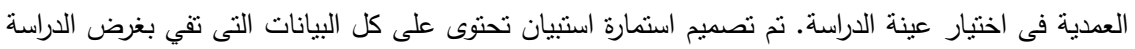

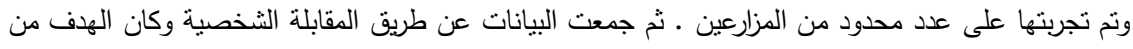
الدراسة هو توصيف خصائص مزارع إنتاج الألبان لمعرفة المعوقات التى تعوق تتمية قطاع الألبان فى صعيد مصر ومن ذلك يمكن وضع توصيات لنطوير هذا القطاع .

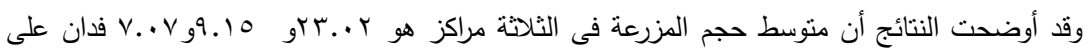

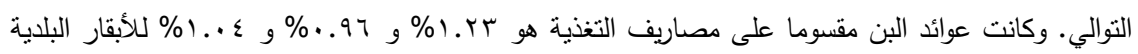

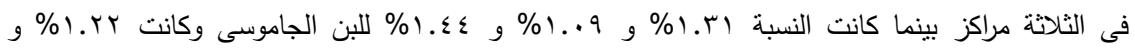

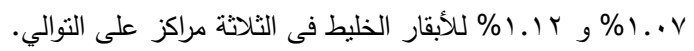
أما عن تغذية الحيوان فكان متوسط استهلاك الحيوانات من الأعلاف الخضراء في الكزان المزرعة في موسم

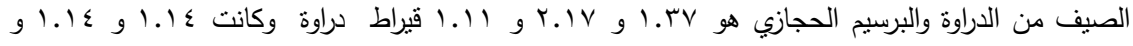

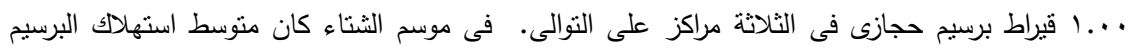

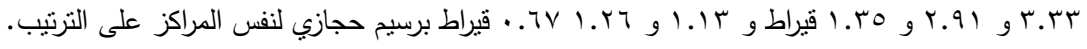

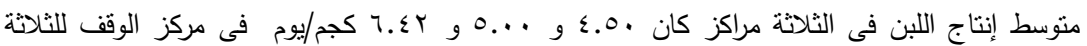

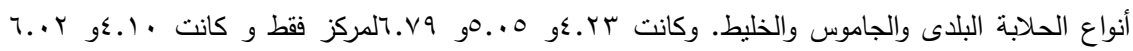

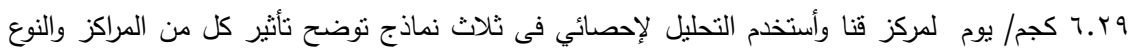

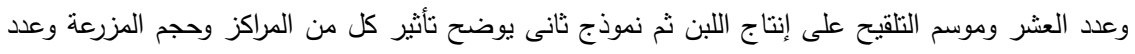

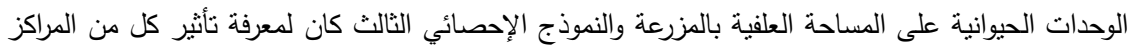
وحجم المزرعة على حيازة الأبقار الحلابة. بصف عامة يوصى بالآتي:

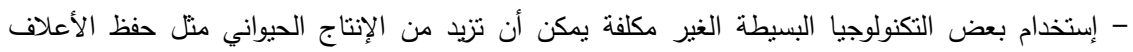
الخضراء أستخدام التلقيح الصناعى ، بعض الإضافات الغذائية مثل المولاس و النباتات الطيبة. 